ISSN : 2087-2461

PENANGGUNG JAWAB Dekan FIKOM Trimanah, M.Si

Sekretaris Fakultas

Dian Marhaeni K, M.Si

Ketua Penyunting Made Dwi Adnjani, M.Si

Sekretaris

Mubarok, M.Si

Bendahara

Parwati, SH

Dewan Penyunting

Edi Ismoyo, M.Si

Drs. Haryoso

Seksi Usaha

Endang Winarsih, S.Sos

Sirkulasi dan Distribusi

Palupi Satwika, Amd.

Alamat Redaksi

Fakultas Ilmu Komunikasi

Universitas Islam

Sultan Agung Semarang

Jl. Raya Kaligawe Km. 4

Po. Box 1054/SM

Semarang 50112

Telp. (024) 6583584

ext. $448 / 449$

Fax. (024) 6582455

email : jurnalfikom@yahoo.com
Konstruksi Teori Komunikasi Dalam Tafsir Al Qur'an Surat Al Fatihah

Mubarok

mubarok@unisula.ac.id

$110-127$

Inovasi Komunikasi Pemasaran Pada RRI Semarang

Agus Triyono

agustriyono7@gmail.com

128-136

Pengaruh Word of Mouth dan Brand Awareness terhadap Intensi Mengunjungi Tempat Wisata Ziarah Makam Sunan Kalijaga Demak

Santi Ratnawati

santirahmawati@ymail.com

$137-148$

Pengaruh Persepsi Downline Tentang Kualitas Jasa Upline Pada Multi Level Marketing Tianshi Terhadap Loyalitas Downline di Malang

(Studi pada jaringan Akhmad Fidzan)

Devi Purnamasari

devi.purnamasari9@g mail.com

149-163

Manajemen Krisis Polri dalam Kasus Penyerangan Lembaga Permasyarakatan Cebongan Sleman Daerah Istimewa Yogyakarta

Iva Anjar Pawestri

iva.anjar89@yahoo.co.id

$164-180$

Identitas Diri Remaja Melalui Status Sosial Facebook

Muna Madrah

munamadrah@unissula.ac.id.

Made Dwi Adnjani

made@unissula.ac.id

$181-198$

Efektifitas Pelaksanaan Kebijakan Joko Widodo dalam Mengentaskan Kemiskinan (Studi Opini Pemegang Kartu Jakarta Sehat dan Kartu Jakarta Pintar di DKI Jakarta)

Indah Suryawati

indahsuryawati_2121@yahoo.com 199-218 


\title{
PENGARUH WORD OF MOUTH DAN BRAND AWARENESS TERHADAP INTENSI MENGUNJUNGI TEMPAT WISATA ZIARAH MAKAM SUNAN KALIJAGA DEMAK
}

\author{
Oleh: \\ Santi Ratnawati \\ Mahasiswa Program Studi Magister Ilmu Komunikasi Universitas Diponegoro \\ santiratnawati@ymail.com
}

\begin{abstract}
Tourism is one of the largest foreign exchange earner, leveling and increase employment opportunities and incomes, strengthen unity, and unity, as well as get to know the culture of the nation. Tourism is also capable give opportunity for jobs. Thus, the optimal management is needed. As part of the delivery of information to the public, tourism can be introduced by way of word of mouth. In addition, a good impression in the minds of the public on a tourist destination, could be the trigger for the decision to visit a tourist attraction.

In daily life, the decision intention to purchase a product or service is often performed as a positive information from someone else, a friend or relative you trust, or information due to the positive experiences of others previously received.

The results showed that the positive information on the existence of Sunan Kalijaga will build a positive perception of the tomb of Sunan Kalijaga prospective visitor, thus building interest or intention to make a visit or re-visit. Meanwhile, a good image in the minds of potential visitors or people who have visited the grave of Sunan Kalijaga will build interest or interests that make re-visit the tomb of Sunan Kalijaga.
\end{abstract}

Keywords: Tourism, Word of Mouth, Brand Awareness, intention.

\begin{abstract}
Abstrak
Pariwisata adalah salah satu penghasil devisa, meratakan dan meningkatkan kesempatan kerja dan pendapatan, memperkokoh persatuan, dan kesatuan, serta mengenal budaya bangsa. Pariwisata juga mampu menciptakan lapangan pekerjaan. Maka, diperlukan pengeloilaan yang optimal untuknya. Sebagai bagian dari penyampaian informasi ke masyarakat, obyek wisata bisa dikenalkan dengan cara word of mouth. Selain itu, kesan yang baik di benak masyarakat atas suatu tujuan wisata, bisa menjadi pemicu atas keputusan mengunjungi suatu obyek wisata.

Dalam kehidupan sehari hari, intensi keputusan untuk pembelian suatu produk atau jasa seringkali dilakukan karena suatu informasi positif dari orang lain, teman atau saudara yang dipercaya, atau informasi karena pengalaman positif yang diterima orang lain sebelumnya.

Hasil penelitian menunjukkan bahwa Informasi yang positif atas keberadaan Sunan Kalijaga akan membangun persepsi yang positif terhadap calon pengunjung makam Sunan Kalijaga, sehingga membangun minat atau intensi untuk melakukan kunjungan ataupun kunjungan ulang. Sementara itu, citra yang bagus pada benak calon pengunjung atau orang yang pernah mengunjungi makam Sunan Kalijaga akan membangun ketertarikan atau minat kembali sehingga melahirkan tindakan untuk mengunjungi kembali makam Sunan Kalijaga.
\end{abstract}

Kata Kunci: Pariwisata, Word of Motuh, Brand Awareness, Intensi. 


\section{Latar Belakang}

Pariwisata mempunyai peranan yang penting dalam pembangunan nasional, yaitu sebagai salah satu penghasil devisa, meratakan dan meningkatkan kesempatan kerja dan pendapatan, memperkokoh persatuan, dan kesatuan, serta mengenal budaya bangsa. Seperti yang telah diamanatkan dalam Garis Besar Haluan Negara (GBHN) tahun 1999, bahwa mengembangkan pariwisata, melalui pendekatan sistem yang utuh dan terpadu bersifat interdisipliner dan partisipatoris dengan menggunakan kriteria ekonomi, teknis, argonomis, sosial budaya, hemat energi, melestarikan alam dan tidak merusak lingkungan. (TAP MPR No.IV/ MPR/1999).

Diakui bahwa sumbangan sektor pariwisata terhadap perolehan devisa dan penciptaan lapangan kerja secara makro cukup signifikan. Laporan berbagai kajian ahli menyimpulkan bahwa sumbangan pariwisata secara signifikan pada perkembangan ekonomi suatu negara tampak dalam bentu perluasan peluang kerja, peningkatan pendapatan dan pemerataan pembangunan spasial. (Damanik, 2013: 3-4).

Sebagai bagian dari penyampaian informasi ke masyarakat, obyek wisata bisa dikenalkan dengan cara word of mouth. Selain itu, kesan yang baik di benak masyarakat atas suatu tujuan wisata, bisa menjadi pemicu atas keputusan mengunjungi suatu obyek wisata. Paket wisata ziarah sejak dulu diminati turis dari Timur Tengah, Asia Tenggara dan negara lainnya. Negaranegara ASEAN telah melakukan kerjasama terkait wisata ziarah, yang disebut Trail of Civilization. (Ulung, 2013: 4-5)

Dalam kehidupan sehari hari, intensi keputusan untuk pembelian suatu produk atau jasa seringkali dilakukan karena suatu informasi positif dari orang lain, teman atau saudara yang dipercaya, atau informasi karena pengalaman positif yang diterima orang lain sebelumnya. Begitu juga, dalam keputusan melakukan kunjungan wisata. Rasa ketertarikan seseorang atas suatu objek wisata, biasanya dipengaruhi oleh informasi positif yang diterima seseorang sehingga menimbulkan minat yang ujungnya lagi adalah pengambilan keputusan untuk memilih suatu objek wisata.

Selain berita dari mulut ke mulut kesadaran akan suatu mereka atau Brand Awareness juga mempunyai peran penting atas intensi pembelian, atau dalam konteks ini adalah intensi mengunjungi makam Sunan Kalijaga. Dalam jurnal yang ditulis oleh Hsin Kuang Chi (2009) menyebutkan bahwa Brand awareness memainkan peran penting dalam intense pembelian karena konsumen cenderung membeli sesuatu yang familier serta produk yang diketahui dengan baik. Sementara itu, penelitian yang dilakukan oleh Hoyer (1990) menyatakan bahwa Brand Awareness mempunyai pengaruh yang penting dalam pilihan konsumen. Ketika konsumen kurang mempunyai pengetahuan utama atau kesadaran pada suatu brand dalam suatu pilihan, taktik pilihan yang handal bisa kurang tersedia.

\section{Kajian Teori}

\subsection{State of Art}

Seringkali, orang bergantung pada saran atau rekomendasi dari teman, kenalan atau mitra bisnis untuk landasan keputusan pembelian mereka. Word of Mouth (WOM) adalah proses berbagi informasi informal antara konsumen tentang produk 
dan jasa. Dalam hal ini, konsumen juga perusahaan, melalui individu dalam yang memiliki kewenangan untuk membuat keputusan dalam proses pembelian. Komunikasi Word of Mouth (WOM) merupakan upaya perusahaan untuk "mendorong, memfasilitasi dan memperkuat pemasaran yang relevan komunikasi antara konsumen".

Pada journal of consumer research oleh Jacquline Johnson Brown dan Peter H Reingen tahun 1987 dari University of Chicago Press dengan judul Socialties and Word of Mouth Referral Behavior dalam jurnalnya menjelaskan analisis pengaruh Word of Mouth berdasarkan perilaku dalam suatu lingkungan yang menunjukkan mengenai perbedaan peranan dalam hubungan sosial yang kuat dan lemah pada fenomena WOM yaitu "kekuatan dalam hubungan yang lemah" yaitu suatu hubungan yang terjadi dalam suatu hubungan yang kuat atau inti, seseorang yang menjadi rekomendasi adalah seseorang yang mempunyai hubungan dekat atau kuat tetapi suatu hubungan tersebut mempunyai kekuatan yang lemah seperti halnya frekuensi interaksi yang jarang dilakukan dan "kekuatan pada hubungan yang kuat" suatu hubungan yang terjadi dengan interaksi yang selalu berlangsung sering dilakukan. Penelitian ini menunjukkan beberapa aspek pada perilaku WOM dalam suatu hubungan perspektif akan mempunyai pengaruh yang kuat dalam penyebaran WOM.

\subsection{Teori-teori}

\subsubsection{Intensi}

Intensi ditentukan oleh sikap terhadap perilaku dan satu set keyakinan tentang bagaimana orang lain ingin kita berperilaku. (LittleJohn, 2008: 77). Intensi adalah hal yang secara personal diinginkan oleh pelaku perbuatan dengan maksud untuk mencapai sasaran yang hendak dituju. Menurut Fishbein dan Ajzen (1975:318), intensi dapat diartikan sebagai kecenderungan untuk melakukan tindakan secara spesifik yang dibatasi secara jelas dalam situasi tertentu. Harapan-harapan, keinginan-keinginan, ambisi-ambisi, cita-cita dan rencana-rencana seseorang semuanya tercakup dalam intensi (Allport dalam Hall dan Lindzey, 1993:31).

Maka dapat dikatakan bahwa intensi merupakan kecenderungan seseorang untuk melakukan sesuatu yang ditentukan oleh sikap seseorang terhadap perilaku dan tentang keyakinan orang yang ingin kita berperilaku. Jadi, intensi bisa muncul dari dalam diri calon pelakunya dan bisa juga dipengaruhi oleh orang lain.

Intensi merupakan komponen konatif dari sikap dan biasanya diungkapkan dengan keinginan untuk membeli oleh konsumen. Semakin positif sikap sesorang terhadap 
suatu merek maka akan semakin besar intensinya untuk melakukan pembelian (Mangkunegara, 1988: 35). Handoko (2000:42) mengartikan bahwa intensi membeli adalah kecenderungan konsumen untuk membeli merek yang paling disukai. Setelah konsumen melakukan evaluasi terhadap beberapa merek, pada akhirnya pilihan akan tertuju pada satu merek yang paling sesuai dengan keinginan konsumen.

Pada dasarnya intensi pembelian dan intensi kunjungan wisata adalah proses yang sama, karena kedua-duanya memerlukan biaya dan untuk mencapai kepuasan. Tujuan konsumen melakukan pembelian suatu produk adalah untuk memuaskan kebutuhan dan keinginannya (Handoko, 2000:21). Demi mendapat kepuasan dari pembeliannya, konsumen akan melakukan pemilihan terhadap produk yang dianggap memiliki kualitas yang baik. Sebelum membeli suatu produk, konsumen akan memiliki harapan mengenai bagaimana produk tersebut seharusnya berfungsi (Sumarwan, 2002:322).

\subsubsection{Word of Mouth}

Dalam teori komunikasi khususnya teori aksi berbicara LittleJohn (2009: 164) menyebut aksi mempengaruhi (perlocutionary act) yang dirancang supaya berpengaruh pada perilaku orang lain. Baik Word of Mouth maupun branding sebenarnya adalah upaya untuk mempengarui orang lain. Dalam konteks ini adalah suatu upaya untuk membuat orang yang belum mengunjungi makam Sunan Kalijaga menjadi tertarik berkunjung dan orang yang sudah berkunjung mengajak orang lain lagi atau melakukan kunjungan ulang.

Dalam kunjungan ke makam Sunan Kalijaga pelaku kunjungan biasanya melakukan secara berkelompok, sehingga aksi kelompok ini juga bisa menjadi bagian dari brand identitas dan komunikasi dalam kelompok ini bisa menjadi daya tarik bagi orang lain untuk ikut dalam aktifitas kelompok. Dalam buku Griffin dituliskan (2009: 227) most communication schoolars believe that discussion among members has a significant effect on the quality of group decision. Tradisional wisdom suggest that talk is the medium, or conduit, throught which information travel between participant (Kebanyakan intelektual komunikasi percaya bahwa diskusi di antara kelompok mempunyai pengaruh yang berarti dalam mutu keputusan kelompok. Kebijaksanaan tradisional menganjurkan bahwa berbicara adalah media, atau konduit, sepanjang perjalanan informasi antar partisipan). 
Schiffman (2000: 294-295) menyatakan bahwa kelompok rujukan yang dirasakan kredibel, menarik, atau berkuasa dapat menimbulkan perubahan sikap dan perilaku konsumen. Jika para konsumen sangat meperhatikan penerimaan dan persetujuan orang-orang yang mereka sukai, yaitu orang-orang yang ingin mereka tiru, atau yang memberi mereka status atau berbagai manfaat lain, mereka mungkin menggunakan pilihan produk atau merek mereka atau sifat-sifat perilaku lainnya. Jika para konsumen sangat memperhatikan kekuasaan yang dapat digunakan seseorang atau kelompok terhadap mereka, mungkin mereka akan memilih produk, atau jasa yang sesuai dengan norma orang atau kelompok itu untuk menghindari ejekan atau hukuman.

Kottler (2009: 255) menyatakan bahwa beberapa pemasar menekankan pada dua bentuk khusus berita dari mulut ke mulut, yaitu pemasaran buzz dan viral. Pemasaran buzz (gossip/ perbincangan) menghasilkan ketertarikan, menciptakan publisitas, dan mengekspresikan informasi relevan baru yang berhubungan dengan merek melalui sarana yang tak terduga atau bahkan mengejutkan. Pemasaran viral (menular seperti virus) adalah bentuk lain berita dari mulut ke mulut yang men- dorong konsumen menceritakan produk atau jasa.

Banyak studi yang menyatakan bahwa WOM positif dapat meningkatkan minat konsumen untuk membeli dan membantu meningkatkan citra yang positif terhadap merek dan perusahaannya serta promosi berupa WOM yang positif akan mempengaruhi minat seseorang untuk melakukan aktivitas atau tindakan yang langsung terlibat dalam mendapatkan, mengkonsumsi dan menghabiskan produk dan jasa. Word of Mouth yang positif dapat bertindak sebagai agen penjualan yang handal dan sangat dipercaya sebaliknya Word of Mouth yang negatif dapat sangat merugikan suatu perusahaan. Word of Mouth adalah suatu komentar positif atau negatif tentang suatu jasa yang disebarkan seseorang (biasanya pelanggan dulu atau sekarang) kepada orang lain. (Loveloc, 2005: 274)

\subsubsection{Kesadaran Merek (Brand Awareness)}

Brand adalah salah satu atribut yang sangat penting dari sebuah produk yang penggunaanya pada saat ini sudah sangat meluas karena beberapa alasan, dimana merek suatu produk berarti memberikan nilai tambah produk tersebut.

Pikiran para pelanggan dipengaruhi oleh 
beragam pesan yang sampai pada angka ribuan pesan dan sering berubah - ubah. Merek tidak hanya kesan - kesannya, tetapi merek juga harus menempati suatu posisi khusus dalam pikiran untuk benar - benar menjadi sebuah merek.

Permasalahannya bila merek tidak mendapat tempat khusus atau berbeda dalam benak konsumen, maka akan memberi kesempatan bagi para pesaing untuk menempati posisi dalam benak konsumen tersebut dan merek itu menjadi kurang sejati. Oleh karena itulah maka diperlukan apa yang dinamakan dengan merek sejati.

Merek sejati terdiri dari tiga hal yang merupakan sifat fundamental yang membedakan merek sejati dalam benak konsumen yakni internalisasi jumlah kesan - kesan, suatu khusus di "pikiran (mind's eye)" konsumen, dan manfaat - manfaat fungsional dan emosional yang dirasakan. Secara definitif merek sejati dapat dijelaskan sebagai internalisasi jumlah dari semua kesan yang diterima para pelanggan dan konsumen yang dihasilkan dalam sebuah posisi khusus di "pikiran" konsumen berdasarkan manfaat - manfaat fungsional dan emosional.

$\mathrm{K}$ e s a d a r a $\mathrm{n}$ (awareness) menggambarkan keberadaan merek di dalam pikiran konsumen, yang dapat menjadi penentu dalam beberapa kategori dan bisaanya mempunyai peranan kunci dalam pembentukan brand equity (Aaker, 1991: 17). Brand equity merupakan sekumpulan aset yang terkait dengan nama merek dan simbol sehingga dapat menambah nilai yang ada dalam produk atau jasa tersebut. Kesadaran merek dapat mempengaruhi persepsi dan tingkah laku konsumen dalam proses pengambilan keputusan pembelian. Jika kesadaran merek sangat rendah, maka hampir dipastikan bahwa ekuitas mereknya juga rendah. Peran Brand Awareness dalam keseluruhan brand equity tergantung sejauh mana tingkat kesadaran yang dicapai oleh sebuah merek.

Menurut Aaker (1991: 18) awareness merupakan bentuk yang paling sederhana dari brand equity yaitu adanya perasaan tidak asing terhadap brand. Perasaan tidak asing terhadap suatu brand akan memberikan rasa percaya diri. Kemudian rasa percaya ini akan menyebabkan adanya perasaan bahwa risiko yang dihadapi oleh pelanggan berkurang, yang pada gilirannya pelanggan berkecenderungan untuk mempertimbangkan dan memilih brand yang bersangkutan. Fakta menunjukkan bahwa rata-rata pelanggan lebih menyukai brand yang telah ia kenal daripada brand yang as- 
ing baginya atau baru saja mereka kenal.

Kesadaran merek memainkan peran penting dalam menciptakan ekuitas merek berbasis pelanggan. Semakin tinggi kesadaran merek akan berpengaruh pada meningkatnya ekuitas merek, kemudian ekuitas merek yang lebih tinggi dapat menimbulkan minat beli yang lebih besar secara signifikan.

\subsubsection{Wisata Ziarah}

Jika merujuk pada Undang-Undang No. 9 tahun 1990 mengenai kepariwisataan Bab I, pasal 1: dijelaskan bahwa wisata adalah kegiatan perjalanan atau sebagian kegiatan tersebut yang dilakukan secara sukarela serta bersifat sementara untuk menikmati objek atau daya tarik wisata.

Dari segi maksud dan tujuan wisata salah satu kriterianya adalah Pilemage Tour atau sering juga disebut dengan wisata keagamaan, yaitu perjalanan wisata dimaksudkan guna melakukan ibadah keagamaan. Suwantara (2004: 16). Sedangkan menurut (Ulung. 2013: 4-5) pariwisata dibagi menjadi beberapa macam sesuai dengan tujuannya, dan salah satunya yaitu, wisata ziarah yang sering disebut juga wisata religi atau wisata spiritual yang berpotensi besar menarik wisatawan domestik serta asing.

\subsubsection{Paradigma Penelitian}

Wouth of mouth adalah proses komunikasi yang menyampaikan suatu informasi mengenai suatu obyek, baik dia produk, jasa, atau objek wisata. Semakin meningkat informasi positif melalui orang yang dipercaya, maka akan semakin meningkatkan minat seseorang atas sesuatu. Sedangkan minat sendiri ditentukan oleh informasi positif yang sesuai dengan tingkat kebutuhan dan keinginan seseorang. Maka, jika informasi yang disampaikan tersebut bernuansa mengajak atau membujuk serta meyakinkan akan semakin meningkatkan minat seseorang.

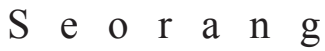
pelanggan biasa berbicara kepada orang lain ketika mencari saran atau opini mengenai suatu merk, jasa, produk atau perusahaan. Dalam literatur pemasaran, hal tersebut dikenal dengan words of mouth (WOM). WOM merupakan suatu mekanisme tertua dimana melalui WOM dapat disebarluaskan, di ekspresikan dan dibangun mengenai opini seseorang terhadap produk, merk, dan jasa (Cengiz dan Yayla, 2007: 73). Arndt (1967) dalam Cengiz dan Yayla (2007 :75) mendefinisikan WOM sebagai komunikasi dari satu orang kepada orang lain, dimana seseorang yang menjadi penerima informasi tidak 
merasakan adanya nilai komersial ketika si pemberi informasi merekomendasi hal-hal yang berkaitan dengan merk, produk atau jasa tertentu.

Sementara itu, kesadaran merek adalah sebuah keadaan tentang kesadaran yang lebih besar dari sesuatu. Sedangkan intensi sendiri ditentukan oleh informasi kesadaran yanglebihbesardarisesuatu. Maka, jika kesadaran yang lebih besar dari sesuatu semakin kuat akan semakin meningkatkan intensi seseorang.

\subsubsection{Teori Komunikasi}

Menurut Richard West \& Lynn H.Turner (2008:5) komunikasi (communication) adalah proses sosial di mana individu-individu menggunakan simbol-simbol untuk menciptakan dan menginterpretasikan makna dalam lingkungan mereka. Komunikasi juga mencakup komunikasi tatap muka maupun komunikasi dengan menggunakan media. Strategi adalah pendekatan secara keseluruhan yang berkaitan dengan pelaksanaan gagasan, perencanaan dan aksekusi sebuah aktivitas dalam kurun waktu tertentu. Konsentrasi komunikasi strategis menurut Sunarto dan kawankawan (2009:2) media sebagai alat persuasi ekonomi, politik, sosial.

Dalam konsep tradisi fenomenologi persepsi
Littlejohn

(2009:58-59) baginya manusia merupakan sosok gabungan antara fisik dan mental yang menciptakan makna di dunia. Kita mengetahui sesuatu hanya melalui hubungan pribadi kita dengan benda tersebut. Sebagai manusia, kita dipengaruhi oleh dunia dengan bagaimana kita mengalaminya. Baginya lagi, segala sesuatu tidak ada sendirinya dan terpisah dari bagaimana semuanya diketehui. Agaknya, manusia memberikan makna pada benda-benda di dunia, sehingga pengalaman fenomena logis apapun tentunya subjektif. Jadi, terdapat dialog antara manusia sebagai penafsir dan benda yang mereka tafsirkan.

\section{Hubungan Antar Variabel}

\subsection{Hubungan antara Word of Mouth dengan intensi}

Penelitian yang dilakukan oleh Francis (1998) menyatakan bahwa Word of Mouth diketahui selama beberapa tahun sebagai pengaruh utama atas apa yang orang ketahui, rasakan dan lakukan. Sementara itu intensi terkait dengan apa yang dirasakan seseorang untuk melakukan sesuatu. Selanjutnya dikatakan bahwa Word of Mouth dapat lebih berpengaruh pada beberapa kondisi yakni, kesadaran, pertimbangan, sikap, intensi perilakuserta perilaku. Berdasarkan keterangan tersebut maka hipotesis yang diajukan dalam penelitian ini yaitu:

H1: Word of Mouth berpengaruh positif terhadap intensi 


\subsection{Brand Awareness}

Brand awareness menggambarkan kesadaran citra di dalam pikiran konsumen. Meningkatnya kesadaran adalah suatu persepsi dan tingkah laku. Jadi kesadaran citra adalah kemampuan konsumen untuk mengingat suatu citra tertentu yang menjadikannya berbeda bila dibandingan hal lain. Kamins (1991) Dalam jurnal yang ditulis oleh Hisn Kuang Chi (2009) dinyatakan bahwa konsumen akan mempunyai intensi pembelian yang tinggi dengan citra yang familier. Selanjutnya penelitian menyimpulkan bahwa identitas citra dan ingatan citra terkait secara positif pada intensi pembelian.

Berdasarkan keterangan tersebut maka hipotesis yang diajukan dalam penelitian ini yaitu:

H1: Word of Mouth berpengaruh positif terhadap intensi

\section{Hipotesis Penelitian}

Menurut Vardiansyah (2008: 10) Hipotesis atau hipotesa adalah jawaban sementara terhadap masalah yang masih bersifat praduga karena masih harus dibuktikan kebenarannya.

Pada dasarnya, komunikasi mempunyai peran dalam memberi informasi pada suatu komunitas, baik itu komunikasi yang bersifat verbal maupun non verbal. Untuk itu, hipotesis dalam penelitian ini adalah:

H1 : Ada pengaruh positif Word of Mouth terhadap intensi kunjungan makam Sunan Kalijaga.

H2 : Ada pengaruh positif Brand Awarenessterhadap intensi kunjungan makam Sunan Kalijaga

\section{Metode Penelitian}

\subsection{Jenis/Tipe Penelitian}

Berdasarkan tujuannya, penelitian ini termasuk dalam penelitian eksplanatori yaitu menjelaskan situasi atau masalah penelitian bersangkutan hubungan sebab akibat kuantitatif. (Arikunto. 2002: 10)

Sementara berdasarkan dimensi waktu, penelitian ini dilakukan secara cross-sectional, yakni hanya melakukan penelitian sekali pada satu waktu tertentu, dengan pertimbangan keterbatasan waktu dan biaya.

Penelitian cross sectional biasanya melibatkan jumlah sampel yang cukup besar dan biasanya dilakukan dengan kuesioner, wawancara pribadi, atau wawancara melalui telepon. Keuntungan penggunaan pendekatan Cross Sectional ini adalah tidak perlu menggunakan banyak pewawancara dan penggunaan waktu yang sedikit. (Faisal. 1995: 22)

\subsection{Teknik Pengumpulan Data}

Penelitian yang digunakan untuk mengumpulkan data informasi adalah dengan menggunakan metode survei melalui instrumen kuesioner. Survei merupakan penelitian yang mengumpulkan data dari sampel pada suatu populasi atau dari responden atas petanyaan yang merupakan pengukuran dari variabel yang diteliti serta menguji hipotesis. Dalam penelitian mengajukan pertanyaan tertulis baik dalam bentuk kuesioner. Penelitian tidak memanipulasi kondisi dan situasi penelitian, dan mengajukan beberapa pertanyaan pada sejumlah kecil subyek (sampel) penelitian dalam jangka waktu relatif singkat. 
Teknik survei di pilih sebab penelitian menggunakan analisa kuantitatif, yang memungkinkan sampel yang diambil cenderung besar, dan penekanannya tidak berdasarkan individu dalam sampel, namun berdasarkan profil general data statistik yang diambil secara individual.

\subsection{Populasi dan Sampel}

Populasi merujuk pada keseluruhan suatu kelompok yang memiliki karakteristik sejenis. Keseluruhan kelompok atau populasi ini dapat berupa manusia, objek, materi, peristiwa dan seterusnya. Ukuran suatu populasi dapat beragam, mulai dari jumlah yang sangat besar hingga ke jumlah sampel yang spesifik.

Sampel didefinisikan
sebagai pengelompokan atau
kumpulan dari elemen pemilihan
sampel atau unit-unit dari populasi
yang spesifik. Kerangka sampel
merupakan keseluruhan daftar
individu yang menjadi satuan
analisis yang berada dalam populasi
dan diambil sampelnya. Teknik
penarikan sampel accidental
dilakukan untuk memudahkan
pengumpulan sampel, yaitu dipilih
100 orang secara acak pada tanggal
15 Oktober 2013 .

\subsection{Teknik Analisis Data}

Analisis data merupakan salah satu proses penelitian yang dilakukan setelah semua data yang diperlukan guna memecahkan permasalahan yang diteliti sudah diperoleh secara lengkap. Ketajaman dan ketepatan dalam penggunaan alat analisis sangat menentukan keakuratan pengambilan kesimpulan, karena itu kegiatan analisis data merupakan kegiatan yang tidak dapat diabaikan begitu saja dalam proses penelitian.

Teknik analisis data yang digunakan dalam penelitian ini adalah dimulai dengan pengumpulan data kuesioner. Kemudian data dianalisis dengan mengukur pengaruh tiap-tiap variabel bebas terhadap variabel terikat dengan menggunakan analisis regresi untuk menguji hipotesis sehingga menghasilkan model persamaan regresi.

Adapun sebelum melakukan analisis regresi akan dilakukan dengan melakukan uji asumsi klasik terhadap variabel-variabel penyusun model persamaan regresi tersebut. Menurut Ghozali (2006: 159) bahwa regresi akan memberikan hasil yang baik jika memenuhi semua asumsi klasik.

\section{Hasil Penelitian dan Pembahasan}

\begin{tabular}{|c|c|c|c|c|}
\hline \multicolumn{5}{|c|}{ Model Summary } \\
\hline Model & $\mathrm{R}$ & $\begin{array}{c}\mathrm{R} \\
\text { Square }\end{array}$ & $\begin{array}{l}\text { Adjusted } \\
\text { R Square }\end{array}$ & $\begin{array}{l}\text { Std. Error of } \\
\text { the Estimate }\end{array}$ \\
\hline 1 & $.848^{\mathrm{a}}$ & .718 & .712 & 3.13247 \\
\hline
\end{tabular}

Hasil uji SPSS versi 16.0 menunjukkan bahwa nilai $\mathrm{R}$ square adalah 0,718 . Hal ini menyatakan bahwa secara bersama-sama word of mouth dan Brand Awareness mempunyai pengaruh sebesar 71,8 persen terhadap intense mengunjungi makan Sunan Kalijaga Kadilangu Demak. Ada sisa 28,2 \% yang dipengaruhi oleh factor lain yang menyebabkan pengunjung makan Sunan Kalijaga mempunyai intensi untuk melakukan kunjungan, tetapi tidak dibahas dalam penelitian ini. 


\section{ANOVA $^{b}$}

\begin{tabular}{|l|r|r|r|c|c|}
\hline \multicolumn{1}{|c|}{ Model } & $\begin{array}{c}\text { Sum of } \\
\text { Squares }\end{array}$ & df & $\begin{array}{c}\text { Mean } \\
\text { Square }\end{array}$ & F & Sig. \\
\hline 1 Regression & 2426.709 & 2 & 1213.355 & 123.655 & .000 \\
\hline Residual & 951.801 & 97 & 9.812 & & \\
\hline Total & 3378.510 & 99 & & & \\
\hline
\end{tabular}

a. Predictors:

(Constant), X2, X1

b. Dependent

Variable: Y

Nilai sig 0,000 pada uji Anova di atas dengan tingkat signiifkansi 0,05 menunjukkan bahwa word of mouth dan Brand Awareness berpengaruh terhadap intense mengunjungi makam Sunan Kalijaga.

\section{Coefficients $^{\mathrm{a}}$}

\begin{tabular}{|l|r|r|r|r|r|}
\hline \multirow{2}{*}{ Model } & \multicolumn{2}{|c|}{$\begin{array}{c}\text { Unstandardized } \\
\text { Coefficients }\end{array}$} & $\begin{array}{c}\text { Standardized } \\
\text { Coefficients }\end{array}$ & \multirow{2}{*}{$\mathrm{t}$} & \multirow{2}{*}{ Sig. } \\
\cline { 2 - 5 } & $\mathrm{B}$ & $\begin{array}{c}\text { Std. } \\
\text { Error }\end{array}$ & \multicolumn{1}{|c|}{ Beta } & & \\
\hline (Constant) & 3.417 & 5.357 & & .638 & .525 \\
\hline $\mathrm{X} 1$ & .446 & .231 & .408 & 1.932 & .056 \\
\hline $\mathrm{X} 2$ & .510 & .241 & .447 & 2.116 & .037 \\
\hline
\end{tabular}

a. Dependent

Variable: Y

Pada tabel di atas menunjukkan bahwa nilai sig pada X1 adalah $0,044<$ 0,05 . Hal ini menunjukkan bahwa secara parsial word of mouth berpengaruh positif terhadap intensi mengunjungi makam Sunan Kalijaga. Sementar itu, nilai sig pada X2 sebesar $0,037<0,05$, Hal ini menunjukkan bahwa secara parsial Brand Awareness berpengaruh positif terhadap intensi mengunjungi makam Sunan Kalijaga.

Informasi yang positif atas keberadaan Sunan Kalijaga akan membangun persepsi yang positif terhadap calon pengunjung makam Sunan Kalijaga, sehingga membangun minat atau intensi untuk melakukan kunjungan ataupun kunjungan ulang. Sementara itu, citra yang bagus pada benak calon pengunjung atau orang yang pernah mengunjungi makam Sunan Kalijaga akan membangun ketertarikan atau minat kembali sehingga melahirkan tindakan untuk mengunjungi kembali makam Sunan Kalijaga.

\section{Kesimpulan dan Saran}

Berita dari mulut ke mulut kesadaran akan suatu merek atau Brand Awareness mempunyai peran penting atas intensi pembelian, atau dalam konteks ini adalah intensi mengunjungi makam Sunan Kalijaga. Untuk itu, menjadi masukan bagi semua pengelola wisata ziarah untuk melakukan pemberitaan dan informasi yang positif kepada setiap orang yang terjangkau sehingga dari tahun ke tahun jumlah pengunjung wisata ziarah akan terus meningkat.

\section{Daftar Pustaka}

Aaker, David. A. (1991). Managing Brand Equity. New York: Maxwell Macmillian Canada.Inc

Buttke, Francis. (1998). Word of Mouth: Understanding anf Managing Referral Marketing. Journal of Strategic Marketing.

Arikunto, Suharsimi, (2002). Prosedur Penelitian, Suatu Pendekatan Praktek. Jakarta: PT. Rineka Cipta.

Damaik,Janianton.2013.PariwisataIndonesia antara Peluang dan Tantangan. Pustaka Pelajar: Yogyakarta.

Faisal, Sanapiah. (1995). Format-format Penelitian Sosial. Grafindo Persada. Jakarta.

Fishbein, M., dan Ajzen, I. 1975. Belief, Attitude, Intention and Behavior: An Introduction to Theory and Research. California: Addison-Wesley

Publishing. 
Fishbein, M dan Ajzen, I. (1975). Belief, Attitude, Intention, and Behavior : An Introduction to Theory and Research. Massachusetts : Addison Wesley Publishing Company.

Griffin, Em. (2009). A First Look at Communication Theory. McGraw-Hill International.

Ghozali, Imam. (2006) Aplikasi Analisis Multivariate dengan Program SPSS. Badan Penerbit Universitas Diponegoro.

Hanna, Nessim - Richard Woznaik. (2001) Consumer Behavior And Applied Approach. Prentice Hall.Inc.Upper Saddle River .New Jersey.

Hoyer, Wayne. (1990). Effects of Brand Awareness on Choice for a Common, Repeat-Purchase Product.

Journal of Consumer Research. Vol. 17. September 1990.

Handoko, Hani. (2000) Manajemen Pemasaran, Analisis Perilaku Konsumen, BPFE: Yogyakarta.

Hsin Kuang Chi. 2009. The Journal of International Management Studies, Volume 4, Number 1, February, 2009 135. The Impact of Brand Awareness on Consumer Purchase Intention: The Mediating Effect of Perceived Quality and Brand Loyalty

LittleJohn. (2009). Teori Komunikasi. Salemba Humanika: Jakarta.

Schiffman, Leon. ((2000). Perilaku Konsumen. Jakarta: Indeks.

Sumarwan, U. (2003). Perilaku Konsumen : Teori dan Penerapannya dalam Pemasaran. PT. Ghalia Indonesia: Jakarta

Sunarto dan kawan-kawan. (2009). Metoda Penelitian Komunikasi Terapan. Semarang: Undip Press.

Undang-Undang No.9 tahun 1990 mengenai kepariwisataan.

Ulung, Gagas. (2013). Wisata Ziarah. Gramedia: Jakarta.

Vardiansyah, Dani. (2008). Filsafat Ilmu Komunikasi: Suatu Pengantar. Indeks: Jakarta,

West, Richard \& Turner, Lynn H. (2008) Pengantar Teori Komunikasi Analisis dan Aplikasi. Buku II Judul asli: Intruducing Communication Theory: Analysis and Aplication. Jakarta: Salemba Humanika. 